\title{
Carotid intima-media thickness among normoglycemia and normotension first-degree relatives of type 2 diabetes mellitus
}

This article was published in the following Dove Press journal: Vascular Health and Risk Management

Dyah Purnamasari ${ }^{1}$ Muhammad Syah Abdaly ${ }^{2}$ Mohamad Syahrir Azizi ${ }^{3}$ Ika Prasetya Wijaya ${ }^{3}$ Pringgodigdo Nugroho 4

'Division of Endocrinology, Department of Internal Medicine, Faculty of Medicine, Universitas Indonesia, Cipto

Mangunkusumo General Hospital, Jakarta, Indonesia; ${ }^{2}$ Department of Internal Medicine, Faculty of Medicine, Universitas Indonesia, Cipto Mangunkusumo General Hospital, Jakarta, Indonesia; ${ }^{3}$ Division of Cardiology, Departement of Internal Medicine, Faculty of Medicine, Universitas Indonesia, Cipto Mangunkusumo General Hospital, Jakarta, Indonesia; ${ }^{4}$ Division of Nephrology, Departement of Internal Medicine, Faculty of Medicine, Universitas Indonesia, Cipto Mangunkusumo General Hospital, Jakarta, Indonesia
Correspondence: Dyah Purnamasari Division of Endocrinology, Department of Internal Medicine, Faculty of Medicine, Universitas Indonesia, Cipto

Mangunkusumo General Hospital,

Salemba Raya 6, Jakarta 10430, Indonesia

Email dyah_P_irawan@yahoo.com
Introduction: Theoretically, first-degree relatives (FDRs) of type 2 diabetes mellitus (T2DM) are predisposed to have earlier and more severe atherosclerosis than non-FDR due to hereditary insulin resistance. A previous study reported that atherosclerotic plaques were found in $45.2 \%$ of young adults FDR of T2DM, but the study did not include non-FDR as control group. The aim of this study was to compare subclinical atherosclerosis (carotid intima-media thickness, CIMT) between FDR of T2DM and non-FDR.

Method: This was a cross-sectional study involving 16 FDR subjects and 16 age-sex matched non-FDR subjects, aged 19-40 years, with normal glucose tolerance and no hypertension. Collected data included demographic characteristic, anthropometric measurement (BMI and waist circumference), laboratory analysis (fasting blood glucose, HbAlc, lipid profile), and CIMT examination (using B-mode ultrasound).

Results: The mean of CIMT in the FDR group was higher than that in the non-FDR group ( 0.44 $\mathrm{mm}$ vs $0.38 \mathrm{~mm}, p=0.005$ ). After adjusting for waist circumference, BMI, low-density lipoprotein cholesterol, and triglyceride, CIMT maintained significant difference between FDR and nonFDR subjects. BMI and waist circumference showed moderate correlation with CIMT.

Conclusion: CIMT in young adult FDR of T2DM is thicker than that in age-and sexmatched non-FDR population.

Keywords: first-degree relatives, type 2 diabetes mellitus, subclinical atherosclerosis, carotid intima-media thickness

\section{Introduction}

Cardiovascular disease (CVD) remains a leading cause of death globally. Recent data in 2013 showed that approximately 17.3 million of the total 54 million deaths per year in the world were caused by CVD. ${ }^{1}$ According to WHO data in 2014, CVD is the leading cause of death in Indonesia, comprising $37 \%$ of all causes of death. $^{2}$

Atherosclerosis is a major underlying cause of CVD, including myocardial infarction, stroke, heart failure, and peripheral artery disease. This condition begins early in childhood and is progressive. Atherosclerosis is often asymptomatic for several decades before manifesting clinically, termed as subclinical atherosclerosis. ${ }^{3,4}$ Cardiovascular risk factors such as hypertension, hyperglycemia, dyslipidemia, and obesity not only play a role in the development of the atherosclerosis process, but also serve as components of insulin-resistance syndrome. $^{5}$ 
One of the risk factors for developing insulin resistance is first-degree relatives (FDRs) who suffer from type 2 diabetes mellitus (T2DM). The FDR group shows the tendency of insulin resistance and pancreatic beta cell function impairment, even in adolescence. ${ }^{6}$ A study showed that normoglycemic FDR of T2DM patients had higher insulin levels, more fat accumulation in muscle, and lower peripheral glucose uptake than in the non-FDR population. ${ }^{7}$ The insulin-resistance FDR group also proved to have impaired coronary artery blood flow and coronary elasticity. ${ }^{8}$ A previous study in Indonesia showed that atherosclerotic lesions were found in $45.2 \%$ normoglycemic and normotensive young adults from FDR population. ${ }^{9}$ However, the study did not include the nonFDR group; therefore, the difference in subclinical atherosclerotic lesions between the two groups was unknown.

\section{Method}

This study was conducted between June and September 2018, involving 16 subjects of FDR T2DM and 16 subjects with non-FDR T2DM, who were matched for age and gender. Sample collection was performed using consecutive sampling method. The FDR subjects were recruited through direct invitation by diagnosed T2DM patients of the Endocrinology Outpatient Clinic at Cipto Mangunkusumo National General Hospital (RSCM). Consecutively, all T2DM patients were asked to allow their offsprings to participate in the study. All of the candidates were given information regarding the study and were screened based on the study criterion. Informed consent was obtained from those who fulfilled the criteria. Other inclusion criteria for the FDR group included men and women aged 19-40 years and who were normoglycemic and normotensive (HbA1c $<5.7 \%$, blood pressure $<140 / 90 \mathrm{mmHg}$ ). For the control group, we recruited nonmedical workers at RSCM, who did not have a family history of T2DM and had similar inclusion criteria with that of the FDR group. Exclusion criteria for both groups were as follows: 1) smoking; 2) history of coronary heart disease, heart failure, arrhythmia, anemia, stroke, transient ischemic attack, peripheral arterial disease, history of hypertension, and diabetes mellitus; 3) taking hypertension drugs, oral contraceptives, or other drugs that might affect lipid and/or glucose metabolism; 4) history of liver disease, kidney disease, and other chronic diseases; and (5) history of acute bleeding or a history of repeated blood transfusions. All subjects signed a written informed consent to be included on a voluntary basis in the study. The study was approved by the Ethics Committee of the Faculty Medicine, University of Indonesia (No:0242/ UN2.F1/ETIK/2018). The written informed consent process was in accordance with the Declaration of Helsinki. Blood pressure measurement was performed using the Riester ${ }^{\circledR}$ sphygmomanometer, which has been calibrated, and a Litmann ${ }^{\circledR}$ stethoscope. Blood pressure was measured by a cuff looped on the upper arm with its center in the brachial artery. During blood pressure measurement, the cuff was inflated until the pulse of the artery disappears and then slowly deflated 3-4 mmHg per second until the arterial pulse returns.

Following that, the subjects underwent anthropometric examination and lipid profile examination after fasting for $12 \mathrm{hrs}$. BMI was calculated using the following formula: weight $(\mathrm{kg}) /$ height $^{2}\left(\mathrm{~m}^{2}\right)$. Weight measurement was measured using the calibrated Shoenle ${ }^{\circledR}$ scales. Height measurement was performed using microtoise height measuring instruments. Waist circumference was measured in order to determine the presence of central obesity ( $\geq 80 \mathrm{~cm}$ in women and $\geq 90 \mathrm{~cm}$ in men, based on NCEP ATP III criteria Asia Pacific modification). Waist circumference measurement was performed by using "Butterfly" measuring tape. This was based on the method determined by WHO. Triglyceride levels, low-density lipoprotein (LDL) cholesterol, high-density lipoprotein (HDL) cholesterol in the patient's blood were evaluated after fasting for at least $12 \mathrm{hrs}$, using the Roche Cobas 501 MMPA tool with an enzymatic colorimetric method.

The carotid intima-media thickness (CIMT) was measured using a B-mode ultrasound. A single operator, who was an internal medicine specialist, carried out the CIMT examination. CIMT was determined by the average result of the measurement of the thickness of the tunica intimamedia on the right common carotid artery (RCCA-IMT) and left common carotid artery (LCCA-IMT), which appeared as a double-line sign longitudinally on the walls of the common carotid artery (CCA). This measurement was using the B-mode ultrasound of the Eccoson $\mathrm{E}$ 66D brand.

Statistical analyses were performed using SPSS version 20.0. The researcher set a two-way hypothesis with the value of $\alpha 1 \%$ and $\beta 10 \%$. A p-value $<0.01$ was considered statistically significant. Subject characteristics are shown in Table 1 and grouped between subjects with FDR T2DM and non-FDR T2DM. Numerical variables with normal distribution were displayed in the form of mean and SD. Numerical data with abnormal distribution were presented 
Table I Demographic and anthropometric characteristics of subjects

\begin{tabular}{|c|c|c|c|}
\hline Variable & $\begin{array}{l}\text { FDR } \\
(n=\mid 6)\end{array}$ & $\begin{array}{l}\text { Non-FDR } \\
(n=16)\end{array}$ & $\begin{array}{l}p- \\
\text { value }\end{array}$ \\
\hline Age (years), average (SD) & $\begin{array}{l}28.81 \\
(6.18)\end{array}$ & $28.81(6.18)$ & 1.00 \\
\hline $\begin{array}{l}\text { Sex, } n(\%) \\
\text { Male } \\
\text { Female }\end{array}$ & $\begin{array}{l}6(37.5) \\
10(62.5)\end{array}$ & $\begin{array}{l}6(37.5) \\
10(62.5)\end{array}$ & 1.00 \\
\hline $\begin{array}{l}\text { Family history of diabetes, } \mathrm{n} \\
\text { (\%) } \\
\text { Father } \\
\text { Mother } \\
\text { Both } \\
\text { No family history }\end{array}$ & $\begin{array}{l}4(25) \\
9(56.3) \\
3(18.8) \\
0(0)\end{array}$ & $\begin{array}{l}0(0) \\
0(0) \\
0(0) \\
16(100)\end{array}$ & $<0.01$ \\
\hline Height $(m)$, average (SD) & $\begin{array}{l}1.59 \\
(0.10)\end{array}$ & $1.62(0.07)$ & 0.31 \\
\hline Weight (kg), average (SD) & $\begin{array}{l}59.24 \\
(9.96)\end{array}$ & $58.24(11.34)$ & 0.79 \\
\hline $\begin{array}{l}\text { Body mass index }\left(\mathrm{kg} / \mathrm{m}^{2}\right) \text {, } \\
\text { average }(\mathrm{SD})\end{array}$ & $\begin{array}{l}23.24 \\
(3.22)\end{array}$ & $21.90(3.46)$ & 0.27 \\
\hline $\begin{array}{l}\text { SBP }(\mathrm{mmHg}), \text { median }(\mathrm{min}- \\
\max )\end{array}$ & $\begin{array}{l}110(90- \\
120)\end{array}$ & $103(90-123)$ & 0.04 \\
\hline $\begin{array}{l}\mathrm{DBP}(\mathrm{mmHg}), \text { median }(\mathrm{min}- \\
\max )\end{array}$ & $\begin{array}{l}70(60- \\
80)\end{array}$ & $70(60-82)$ & 0.49 \\
\hline $\begin{array}{l}\text { Waist circumference }(\mathrm{cm}) \text {, } \\
\text { average }(\mathrm{SD})\end{array}$ & $\begin{array}{l}78.35 \\
(9.86)\end{array}$ & $77.69(10.45)$ & 0.85 \\
\hline
\end{tabular}

Note: The mean difference was considered statistically significant if $p<0.01$. Abbreviations: SBP, systolic blood pressure; DBP, diastolic blood pressure; FDR, first-degree relative.

in median and minimum-maximum values. Shapiro-Wilk test was conducted to assess the normality of the data distribution due to the number of subjects $(<50)$. The distribution of data was considered normal if $\mathrm{p}>0.05$. Bivariate analysis was conducted between confounding variables and the dependent variable using the Pearson test if the data distribution is normal or Spearman test if the data distribution is not normal. Variables from bivariate analysis that showed $\mathrm{p}<0.25$ were assessed by multivariate analysis using linear regression. The results of bivariate and multivariate analysis were considered significant if the value showed $\mathrm{p}<0.05$.

\section{Results}

The mean age of the subjects in both groups was 28.81 years, each with a SD of 6.18 years. Most subjects were female $(62.5 \%)$ (Table 1). Our results showed that 9 subjects $(56.3 \%)$ had mothers with T2DM, 4 subjects $(25 \%)$ had fathers with T2DM, and 3 subjects (18.8\%) had both parents with T2DM (Table 1). The average BMI of FDR subjects was $23.24 \mathrm{~kg} / \mathrm{m}^{2}$ (Table 1). When compared with FDR subjects, non-FDR subjects had a lower average BMI than those with FDR $\left(21.9 \mathrm{~kg} / \mathrm{m}^{2}\right)$ (Table 1). FDR subjects had higher waist circumference than that of non-FDR $\{78.35$ (SD 9.86) $\mathrm{cm}$ vs 77.69 (SD 10.45) $\mathrm{cm}\}$ (Table 1).

Because the distribution of HbA1c data is not normal, the average HbAlc cannot be shown. The average fasting blood glucose in the FDR subject is 87.44 (SD 9.19) $\mathrm{g} / \mathrm{dl}$. The mean LDL cholesterol in this study was 126.06 (SD 44.41) $\mathrm{mg} / \mathrm{dL}$ on the subject of FDR. Non-FDR subjects had a lower LDL cholesterol. The mean HDL cholesterol in this study was 52.06 (SD 10.36) $\mathrm{mg} / \mathrm{dl}$ in the FDR group. While the non-FDR group have lower HDL cholesterol mean. Triglyceride levels in this study in both FDR and non-FDR subjects did not have normal data distribution so that triglyceride levels could not be shown. The characteristics of the research subject based on the results of laboratory examinations can be seen in Table 2.

The mean thickness of tunica intima-media of the left carotid artery (LCCA-IMT) in the subject of FDR was 0.45 (SD 0.08) $\mathrm{mm}$. The mean LCCA intima-media thickness in non-FDR subjects was $0.38(\mathrm{SD} \pm 0.06) \mathrm{mm}$. There was no statistically significant difference between the mean LCCA-IMT in FDR subjects compared to nonFDR subjects $(\mathrm{p}=0.015)$ (Table 3$)$.

Table 2 Lipid and glycemic profile among FDR and non-FDR of T2DM

\begin{tabular}{|c|c|c|c|}
\hline Variable & $\begin{array}{l}\text { FDR } \\
(n=16)\end{array}$ & $\begin{array}{l}\text { Non-FDR } \\
(n=16)\end{array}$ & $\begin{array}{l}\mathrm{p}- \\
\text { value }\end{array}$ \\
\hline $\begin{array}{l}\text { HbAlc (\%), median (min- } \\
\max )\end{array}$ & $\begin{array}{l}5.15 \\
(4.60- \\
5.50)\end{array}$ & $\begin{array}{l}5.20(4.00- \\
5.60)\end{array}$ & 0.58 \\
\hline $\begin{array}{l}\text { Fasting blood glucose (mg/ } \\
\mathrm{dl}) \text {, average (SD) }\end{array}$ & $\begin{array}{l}87.44 \\
(9.19)\end{array}$ & 83.81 (7.96) & 0.34 \\
\hline $\begin{array}{l}\text { Total cholesterol }(\mathrm{mg} / \mathrm{dL}) \text {, } \\
\text { average }(\mathrm{SD})\end{array}$ & $\begin{array}{l}190.81 \\
(46.70)\end{array}$ & $\begin{array}{l}185.38 \\
(25.43)\end{array}$ & 0.69 \\
\hline $\begin{array}{l}\text { LDL cholesterol }(\mathrm{mg} / \mathrm{dL}) \text {, } \\
\text { average }(\mathrm{SD})\end{array}$ & $\begin{array}{l}126.06 \\
(44.4 I)\end{array}$ & $\begin{array}{l}124.75 \\
(23.40)\end{array}$ & 0.92 \\
\hline $\begin{array}{l}\text { HDL cholesterol }(\mathrm{mg} / \mathrm{dL}) \text {, } \\
\text { average }(\mathrm{SD})\end{array}$ & $\begin{array}{l}52.06 \\
(10.36)\end{array}$ & $50.25(12.26)$ & 0.66 \\
\hline $\begin{array}{l}\text { Triglyceride, median (min- } \\
\max \text { ) }\end{array}$ & $\begin{array}{l}74(42- \\
221)\end{array}$ & $\begin{array}{l}78.50(54- \\
167)\end{array}$ & 0.49 \\
\hline
\end{tabular}

Note: The mean difference was considered statistically significant if $p<0.01$. Abbreviations: LDL, low-density lipoprotein; HDL, high-density lipoprotein; FDR, first-degree relative. 
Table 3 Results of carotid intima-media thickness examination

\begin{tabular}{|l|l|l|l|}
\hline Examination & $\begin{array}{l}\text { FDR } \\
(\mathbf{n}=\mathbf{l 6})\end{array}$ & $\begin{array}{l}\text { Non-FDR } \\
(\mathbf{n}=\mathbf{1 6})\end{array}$ & $\mathbf{p}$ \\
\hline LCCA-IMT (mm), aver- & 0.45 & $0.38(0.06)$ & $\mathrm{p}=0.015$ \\
age (SD) & $(0.08)$ & & \\
RCCA-IMT (mm), med- & 0.42 & $0.37(0.32-$ & $\mathrm{p}=0.015$ \\
ian (min-max) & $(0.33-$ & $0.44)$ & \\
& $0.59)$ & & \\
CIMT (mm), average (SD) & 0.44 & $0.38(0.05)$ & $\mathbf{p}=\mathbf{0 . 0 0 5}$ \\
& $(0.06)$ & & \\
\hline
\end{tabular}

Notes: The mean difference was considered statistically significant if $p<0.0$ I. Bold value indicates the difference of CIMT between 2 groups is statistically significant. Abbreviations: LCCA-IMT, left common carotid artery-intima media thickness; RCCA-IMT, right common carotid artery-intima media thickness; CIMT, carotid intima-media thickness (LCCA-IMT+RCCA-IMT/2); FDR, first-degree relative.

Table 4 Correlation of CIMT with confounding variables

\begin{tabular}{|l|l|l|}
\hline \multirow{2}{*}{ Variable } & \multicolumn{2}{|l|}{ CIMT } \\
\cline { 2 - 3 } & $\mathbf{r}$ & p-value \\
\hline BMI & 0.479 & 0.006 \\
LDL cholesterol & 0.342 & 0.056 \\
HDL cholesterol & -0.144 & 0.433 \\
Waist circumference & 0.539 & 0.001 \\
Triglyceride & 0.258 & 0.155 \\
\hline
\end{tabular}

Abbreviations: CIMT, carotid intima-media thickness; LDL, low-density lipoprotein; HDL, high-density lipoprotein.

The median thickness of the right intima-media of the carotid artery (RCCA-IMT) in the FDR subject was 0.42 $\mathrm{mm}$, ranging from 0.33 to $0.59 \mathrm{~mm}$. The median RCCAIMT in non-FDR subjects was $0.37 \mathrm{~mm}$, ranging from 0.32 to $0.44 \mathrm{~mm}$. There were no statistically significant differences between the mean RCCA-IMT in FDR subjects compared to non-FDR subjects $(\mathrm{p}=0.015)$ (Table 3 ).

The mean thickness of the carotid artery intima-media (CCA-IMT) on FDR subjects was 0.44 (SD 0.06) $\mathrm{mm}$. The mean CCA-IMT in non-FDR subjects was 0.38 (SD 0.05) $\mathrm{mm}$. A statistically significant difference was found between the mean CCA-IMT in FDR subjects compared to non-FDR subjects $(\mathrm{p}=0.005)$ (Table 3$)$.

Several factors that were estimated as confounding variables were BMI, waist circumference, LDL cholesterol, HDL cholesterol, and triglyceride (Table 4).

Variables with $\mathrm{p}<0.25$ in bivariate analysis were included in the multivariate analysis. A statistically significant difference was found in the mean CIMT between FDR and non-FDR $(\mathrm{p}<0.01)$, after the addition of confounding variables, which were waist circumference, BMI, LDL cholesterol, and triglycerides.

\section{Discussion}

This study was performed to a specific population, which was a healthy population with a family history of T2DM. The FDR T2DM population had a greater cardiovascular risk factor when compared to the population without a family history of T2DM; therefore, this study might provide a beneficial data to emphasize the early prevention of the onset of T2DM and other cardiovascular complications.

The subjects involved were native Indonesians of indigenous Indonesian descent to minimize the influence of ethnical variations on the assessed parameters, which were CIMT. Ideally, subject screening should consider tribal factors, but considering the heterogenous population that resides in Jakarta, it was difficult to find subjects from one ethical group.

Most of the study participants were female, with as many as 10 women (62.5\%) out of a total of 16 subjects in each group. This might be due to the reason that many male subjects were excluded due to smoking. In addition, most of the male subjects were working; therefore, it was challenging to participate in the study. This difference in gender proportion also occurred in similar studies in Brazil and Italy where female subjects had higher representation than male subjects. ${ }^{10,11}$

The mean age of this research subject was 28.81 $(\mathrm{SD} \pm 6.18)$ years. This study was performed to people $<40$ years with the consideration that age is one of the factors that influence the thickness of the intima-media tunica of the carotid artery; therefore, it is expected that in young adults the age factor is not major. In addition, with the recognition of atherosclerotic lesions at a younger age is expected to be a consideration for early screening; therefore, an intervention can be initiated early. The mean age in this study was similar to that in the Pannacciulli study, in 2003, which include FDR and non-FDR group whose age around 30 and 29.4 years, respectively,. ${ }^{10}$ Similar studies in India in 2006 and 2017 also showed similar age range in FDR and non-FDR group (age 2730.84 years and 28.21-28.30 years, respectively). ${ }^{12,13}$

The average BMI of FDR subjects in this study was $23.24(\mathrm{SD} \pm 3.22) \mathrm{kg} / \mathrm{m}^{2}$. Non-FDR subjects had a mean BMI of $21.90(\mathrm{SD} \pm 3.46) \mathrm{kg} / \mathrm{m}^{2}$. Our finding regarding BMI was similar to the study published by Kumar, which reported that the mean BMI in FDR subjects was $23.28 \mathrm{~kg} /$ $\mathrm{m}^{2}$ with a SD of $3.48 \mathrm{~kg} / \mathrm{m}^{2.13}$ Meanwhile, similar studies conducted outside of Asia reported that the average BMI 
of FDR subjects was greater than that in this study, which was around $25.04(\mathrm{SD} \pm 3.24) \mathrm{kg} / \mathrm{m}^{2}$ and $32.1(\mathrm{SD}$ $\pm 0.63) \mathrm{kg} / \mathrm{m}^{2} \cdot{ }^{10,11}$

BMI and body fat percentage vary between ethnic groups globally. With the same age, gender, and body fat percentage, it showed that the African American had a lower BMI of $1.3 \mathrm{~kg} / \mathrm{m}^{2}$ and the Polynesian ethnic group had a lower BMI of $4.5 \mathrm{~kg} / \mathrm{m}^{2}$ when compared to Caucasians. Chinese ethnicity, Ethiopian, Indonesian, and Thai had a BMI of $1.9 \mathrm{~kg} / \mathrm{m}^{2}, 4.6 \mathrm{~kg} / \mathrm{m}^{2}, 3.2 \mathrm{~kg} / \mathrm{m}^{2}$, and $2.9 \mathrm{~kg} / \mathrm{m}^{2}$ lower than Caucasians, respectively. Differences in body fat percentage and BMI are also found between Caucasians in Europe and America, where Europeans have a body fat percentage of $3.8 \%$ greater than that of Americans on the same BMI. This difference might be caused by energy intakes, body compositions, and energy expenditure that might differ between these ethnicities. ${ }^{14}$ Inter-ethnicity in Asia also has variations in the relationship between body fat percentage and BMI. Within the same BMI, age, and gender, India had a greater body fat percentage than that of Malay. ${ }^{15}$

Waist circumference was used as another anthropometric parameter to assess the risk of insulin resistance. In our study, FDR subjects had bigger waist circumference than that of non-FDR $\{78.35$ (SD 9.86) cm vs 77.69 (SD $10.45) \mathrm{cm}$, respectively $\}$. Besides BMI, several studies outside Asia also showed agreater waist circumference, both in FDR and in non-FDR subjects, than that in Asia. A study in Italy reported waist circumferences among FDR and non-FDR of T2DM were 100.3 (SD 1.54) $\mathrm{cm}$ and 97.7 (SD 1.37) $\mathrm{cm}$, respectively. ${ }^{10}$

Measurements of the intima-media thickness of the CCA is useful due to the high reproducibility because the atherosclerotic process appears as diffuse thickening due to proliferation of smooth muscle cells and extracellular matrix deposits in this segment of the vessel, compared to the internal carotid artery where the manifestation of the atherosclerotic process appears as plaque (focal atherosclerosis). ${ }^{11}$

In our study, the mean of CIMT in the FDR group was significantly higher than that in the non-FDR group $\{0.44$ (SD 0.06) $\mathrm{mm}$ vs 0.38 (SD 0.05) $\mathrm{mm}, \mathrm{p}=0.005\}$. The results of this study were in line with previous studies that examined the tunica-intima thickness of the carotid artery media on FDR subjects. ${ }^{10-13}$

There are a limited number of studies that measure the thickness of the tunica intima-media of the carotid artery, especially in high-risk populations in Indonesia. Previous studies in Indonesia conducted by Purnamasari in 2011 reported a thick median of the tunica intima-media of the carotid artery in 62 FDR subjects was $0.56 \mathrm{~mm}$ with arange of $0.42-1.50 \mathrm{~mm}^{9}$ When compared with the study, the carotid tunica intima-media thickness in this study population was smaller. This difference may be due to the extensive age range of the subjects in this study (19-40 years) and because the exclusion criteria were more strict in this study. Third, this difference might be influenced by the different techniques used by operators. However, the thickness of the average tunica intima-media of the carotid artery in this study was relatively similar when compared to the study by Maarifat in Jakarta, involving 96 healthy subjects with or without cardiovascular risk. This study reported that the mean thickness of the right and left tunica intima-media of the carotid artery in the population of 20-30 years is $0.4 \mathrm{~mm}$ $(0.04 \mathrm{~cm}){ }^{16}$

Factors that correlate to thickness of the carotid artery intima-media in this study included waist circumference and BMI. BMI and waist circumference have a relationship with insulin resistance. In obese subjects who were still sensitive to insulin, insulin plays a role in inhibiting upregulation of inflammatory markers circulating in the blood. Conversely, insulin-resistant obese subjects have high levels of inflammatory markers due to impaired insulin inhibitory effects. ${ }^{17}$ Acute-phase protein increases as a result of insulin resistance, which will result in endothelial dysfunction and atherogenesis. ${ }^{18}$

In our study, after multivariate analysis was carried out to eliminate the effects of confounding variables such as BMI, waist circumference, LDL cholesterol, and triglycerides, there was still a difference in thickness of the carotid artery intima-media which was statistically significant between FDR subjects and non-FDR subjects. This indicates that DM genetic factors still have a major role in the occurrence of subclinical atherosclerosis.

A point mutation from mitochondrial DNA (mtDNA) at nucleotide position $3243 \mathrm{~A}$ to $\mathrm{G}$ is a pathogenetic factor for diabetes. ${ }^{19}$ Damage to mtDNA by reactive oxygen species (ROS) will result in ATP production dysfunction and cause an increase in ROS which will result in subsequent mtDNA mutations. ${ }^{20}$ Mitochondrial DNA polymorphism is also associated with the development of atherosclerosis, which is thought to have an effect on the process of oxidative phosphorylation and production of ROS in mitochondria. ${ }^{21}$ In diabetic patients, both hyperglycemia and hyperinsulinemia can increase oxidative 
stress so that diabetes itself will increase mtDNA damage due to ROS. ${ }^{22}$ In vivo and invitro studies explain that oxidative stress due to hyperglycemia can result in atherogenesis. $^{23}$

Several studies report many polymorphisms associated with atherosclerosis, one of which is the insertion/deletion polymorphism of angiotensin-converting enzyme (ACE I/ D). ${ }^{24}$ A previous study showed that there were no differences in atherosclerotic or carotid artery intima-media thickness in the three ACE gene genotypes; in other words, there was no relationship between ACE gene I/D polymorphism and early atherosclerosis in the FDR population of type 2 DM subjects. ${ }^{9}$ The study showed that in the atherosclerosis process, the influence of risk factors other than renin angiotensin aldosterone (RAA) system may be more dominant; therefore more studies are still needed to assess the genetic polymorphism in FDR T2DM subjects on the incidence of atherosclerosis. In addition to the ACE I/D polymorphism, the researcher also found p22phox polymorphism, the subunit of NAD(P)H oxidase associated with atherosclerosis. ${ }^{25}$ However, as far as the knowledge of the researcher, the study examining this polymorphism in the FDR T2DM population is still very limited.

To the best of our knowledge, this is the first study in Indonesia to examine subclinical atherosclerosis in a young adult FDR of T2DM patients. Although there were several studies outside of Indonesia that showed the differences in the thickness of the carotid artery intimamedia tunica in FDR and non-FDR subjects, this study still has an important role to detect subclinical atherosclerosis in FDR populations in Indonesia, especially young adults who are still normoglycemic and normotensive.

There were several limitations of the study. First, our sample size is small which limits generalization of our results. Second, for the recruitment of non-FDR subjects, to exclude family history of diabetes, we heavily relied on the interview. This study did not directly assess the level of HbAlc of both parents of the subjects, due to the limited funds and difficulties in presenting both parents of the subjects therefore signify a recall bias. In addition, B-mode ultrasound to measure CIMT was assessed by using a manual measurement. However, possible errors can be minimized by the same operator to measure CIMT blindly between FDR and non-FDR subjects. In this study, we did not examine inflammatory markers in order to see the role of inflammation in the pathogenesis of subclinical atherosclerosis.

\section{Conclusion}

The tunica intima-media of the carotid artery in the young adult FDR of T2DM who are normoglycemic and normotensive is thicker than that in non-FDR T2DM.

\section{Acknowledgments}

The authors would like to thank Research and Society Services Directorate, Universitas Indonesia for supporting the finance of this research; and the Cluster Metabolic and Vascular Aging, Indonesian Medical Education and Research Institute (IMERI) team for their support in collecting blood sample and ultrasonography examination.

\section{Disclosure}

The authors report no conflicts of interest in this work.

\section{References}

1. Benjamin EJ, Blaha MJ, Chiuve SE, et al. Heart disease and strokes statistics-2017 update: a report from the American Heart Association. Circulation. 2017;135(10):e146-e603.

2. Erwinanto E, Santoso A, Putranto JNE, et al. Coronary artery disease in the developing world. J Kardiol Indones. 2013;34(4):7-15.

3. Strong JP, Malcom GT, Mcmahan CA, et al. Prevalence and extent of atherosclerosis in adolescents and young adults. JAMA. 1999;281 (8):727-735. doi:10.1001/jama.281.8.727

4. Golden SH, Folsom AR, Coresh J, Sharrett R, Szklo M, Brancati F. Risk factor groupings related to insulin resistance and their synergistic effects on subclinical atherosclerosis. Diabetes. 2002;51 (10):3069-3076. doi:10.2337/diabetes.51.10.3069

5. Federa TID, Ex N. Prevalence of the metabolic syndrome among a racially/ethnically diverse group of U.S. eighth-grade adolescents and associations with fasting insulin and homeostasis model assessment of insulin. Diabetes. 2008;31(10):145.

6. Arslanian S, Bacha F, Saad R, Gungor N. Family history of type 2 diabetes is sensitivity and an impaired balance between insulin sensitivity and insulin secretion in white youth. Diabetes Care. 2005;28 (1):127-130. doi:10.2337/diacare.28.1.115

7. Warram JH, Martin BC, Krolewski AS, Soeldner JS, Kahn CR. Slow glucose removal rate and hyperinsulinaemia precede the development of type II diabetes in the offspring of diabetic patients. Ann Inter Med. 1990;113:909-915. doi:10.7326/00034819-113-12-909

8. Ikonomidis I, Lambadiari V, Pavlidis G, et al. Insulin resistance and acute glucose changes determine arterial elastic properties and coronary flow reserve in dysglycaemic and first-degree relatives of diabetic patients. Atherosclerosia. 2015;241(2):455-462. doi:10.1016/j.atherosclerosis.2015.06.006

9. Purnamasari D, Widjojo BD, Antono D, Syampurnawati M. ACE gene polymorphism and atherosclerotic lesion of carotid artery among offsprings of type 2 diabetes mellitus. Acta Med Indones. 2012;44(2):128-134.

10. Pannacciulli N, Pergola GD, Ciccone M, Rizzon P, Giorgino F, Giorgino R. Effect of family history of type 2 diabetes on the intima-media thickness of the common carotid artery in normalweight, overweight, and obese glucose-tolerant young adults. Diabetes Care. 2003;26(4):1230-1234. doi:10.2337/diacare.26. 4.1230 
11. Prado SS, Ribeiro ML, Cardoso GP, Santos KB, Velarde LGC, Nobrega ACL. Carotid artery structural and functional evaluation in relatives of type 2 diabetic patients. Arq Bras Cardiol. 2009;92(3):186-192.

12. Ahmad J, Ahmed F, Siddiqui MA, Hameed B, Ahmad I. Inflammation, insulin resistance and carotid IMT in first degree relatives of north Indian type 2 diabetic subjects. Diabetes Res Clin Pract. 2006;73(2):205-210. doi:10.1016/j.diabres.2006.01.009

13. Dash DK, Choudhury AK, Singh M, Mangaraj S, Mohanty BK, Baliarsinha AK. Effect of parental history of diabetes on markers of inflammation, insulin resistance and atherosclerosis in first degree relatives of patients with type 2 diabetes mellitus. Diabetes Metab Syndr Clin Res Rev. 2018;12(3):285-289.

14. Deurenberg P, Yap M, van Staveren WA. Body mass index and percent body fat: a meta analysis among different ethnic groups. Int J Obes. 1998;22(12):1164-1171. doi:10.1038/sj.ijo.0800741

15. Deurenberg P, Deurenberg-Yap M, Guricci S. Asians are different from Caucasians and from each other in their body mass index/body fat percent relationship. Obes Rev. 2002;3(3):141-146. doi:10.1046/ j.1467-789X.2002.00065.x

16. Maarifat NN. Ketebalan kompleks intima media arteri karotis komunis pada kelompok khusus usia 20-30 tahun di bagian Radiologi FKUI RSCM [Thesis]. Jakarta: Bagian Radiologi FKUI-RSCM; 2005. Indonesian.

17. Haffner SM. Insulin resistance, inflammation, and the prediabetic state. Am J Cardiol. 2003;92(4 A):18-26.

18. Schmidt MI, Duncan BB, Sharrett AR, et al. Markers of inflammation and prediction of diabetes mellitus in adults (Atherosclerosis Risk in Communities Study): a cohort study. Lancet. 1999;353(9165):16491652. doi:10.1016/S0140-6736(98)09449-5
19. Van Den Ouweland JM, Lemkes HH, Ruitenbeek W, Sandkuijl LA, de Vijlder MF, Struyvenberg PA. Mutation in mitochondrial tRNA (Leu)(UUR) gene in a large pedigree with maternally transmitted type II diabetes mellitus and deafness. Nat Genet. 1992;1:368-371. doi:10.1038/ng0892-368

20. Nomiyama T, Tanaka Y, Piao L, et al. Accumulation of somatic mutation in mitochondrial DNA and atherosclerosis in diabetic patients. Ann NY Acad Sci. 2004;1011:193-204. doi:10.1196/ annals. 1293.020

21. Golubenko MV, Salakhov RR, Makeeva OA, et al. Association of mitochondrial DNA polymorphism with myocardial infarction and prognostic signs for atherosclerosis. Mol Biol. 2015;49(6):968-976. doi:10.1134/S0026893315050088

22. Dandona P, Thusu K, Cook S, et al. Oxidative damage to DNA in diabetes mellitus. Lancet. 1996;347:444-445. doi:10.1016/S01406736(96)90013-6

23. Nishikawa T, Edelstein D, Du XL, et al. Normalizing mitochondrial superoxide production blocks three pathways of hyperglycaemic damage. Nature. 2000;404:789-790. doi:10.1038/ 35008121

24. Cambien F, Poirier O, Lecerf L, et al. Deletion polymorphism in the gene for angiotensin-converting enzyme is a potent risk factor for myocardial infarction. Nature. 1992;359:641-644. doi:10.1038/ $359641 \mathrm{a} 0$

25. Viedt C, Soto U, Krieger-Brauer HI, et al. Differential activation of mitogen-activated protein kinases in smooth muscle cells by angiotensin II. Arterioscler Thromb Vasc Biol. 2000;20:940-948. doi:10.1161/01.ATV.20.4.940
Vascular Health and Risk Management

\section{Publish your work in this journal}

Vascular Health and Risk Management is an international, peerreviewed journal of therapeutics and risk management, focusing on concise rapid reporting of clinical studies on the processes involved in the maintenance of vascular health; the monitoring, prevention and treatment of vascular disease and its sequelae; and the involvement

\section{Dovepress}

of metabolic disorders, particularly diabetes. This journal is indexed on PubMed Central and MedLine. The manuscript management system is completely online and includes a very quick and fair peerreview system, which is all easy to use. Visit http://www.dovepress com/testimonials.php to read real quotes from published authors. 